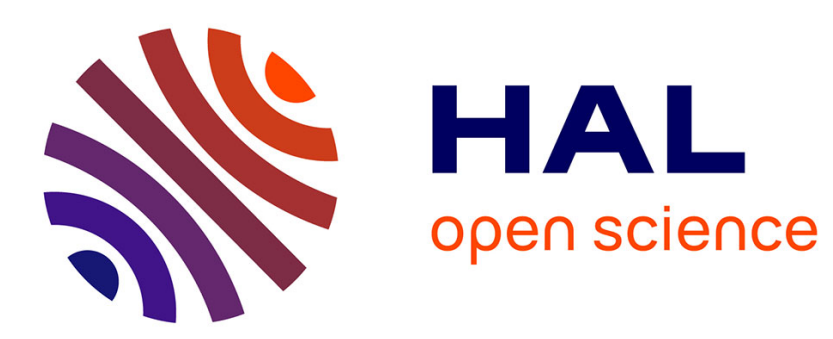

\title{
Remote influence of off-shore fish farm waste on Mediterranean seagrass () meadows
}

\author{
J.M. Ruiz, C. Marco-Méndez, J.L. Sánchez-Lizaso
}

\section{To cite this version:}

J.M. Ruiz, C. Marco-Méndez, J.L. Sánchez-Lizaso. Remote influence of off-shore fish farm waste on Mediterranean seagrass () meadows. Marine Environmental Research, 2010, 69 (3), pp.118. 10.1016/j.marenvres.2009.09.002 . hal-00565102

\section{HAL Id: hal-00565102 \\ https://hal.science/hal-00565102}

Submitted on 11 Feb 2011

HAL is a multi-disciplinary open access archive for the deposit and dissemination of scientific research documents, whether they are published or not. The documents may come from teaching and research institutions in France or abroad, or from public or private research centers.
L'archive ouverte pluridisciplinaire HAL, est destinée au dépôt et à la diffusion de documents scientifiques de niveau recherche, publiés ou non, émanant des établissements d'enseignement et de recherche français ou étrangers, des laboratoires publics ou privés. 


\section{Accepted Manuscript}

Remote influence of off-shore fish farm waste on Mediterranean seagrass (Posidonia oceanica) meadows

J.M. Ruiz, C. Marco-Méndez, J.L. Sánchez-Lizaso

PII:

S0141-1136(09)00119-6

DOI:

10.1016/j.marenvres.2009.09.002

Reference:

MERE 3368

To appear in:

Marine Environmental Research

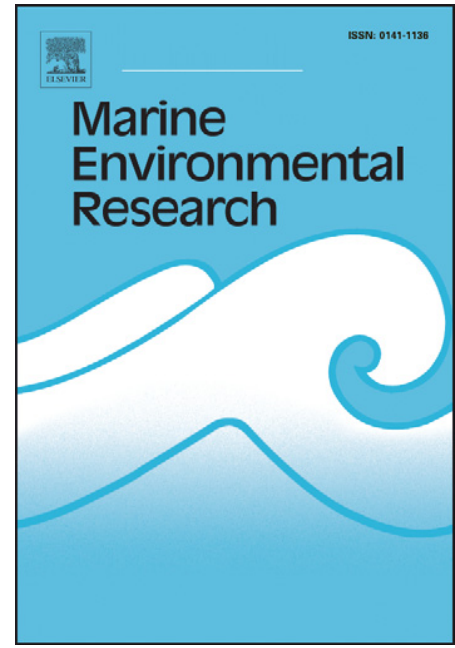

Received Date: $\quad 10$ June 2009

Revised Date: $\quad 1$ September 2009

Accepted Date: $\quad 2$ September 2009

Please cite this article as: Ruiz, J.M., Marco-Méndez, C., Sánchez-Lizaso, J.L., Remote influence of off-shore fish farm waste on Mediterranean seagrass (Posidonia oceanica) meadows, Marine Environmental Research (2009), doi: 10.1016/j.marenvres.2009.09.002

This is a PDF file of an unedited manuscript that has been accepted for publication. As a service to our customers we are providing this early version of the manuscript. The manuscript will undergo copyediting, typesetting, and review of the resulting proof before it is published in its final form. Please note that during the production process errors may be discovered which could affect the content, and all legal disclaimers that apply to the journal pertain. 
1 Remote influence of off-shore fish farm waste on Mediterranean seagrass

2 (Posidonia oceanica) meadows.

3

4 


\section{Abstract}

The aim of this study was estimating the remote influence of waste dispersed

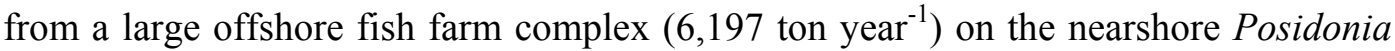
oceanica meadow (26-27 $\mathrm{m}$ deep) located at a distance of $3 \mathrm{~km}$. Measurements of isotopic nitrogen content in epiphytes and seagrass leaf tissues, epiphyte biomass, shoot size, herbivory pressure, shoot density and seagrass meadow cover, performed in this meadow (FA area) were compared with those obtained in an undisturbed control meadow (CA area) to evaluate: (1) the remote influence of waste and (2) the impact of such influence on seagrass condition. In adition, $\delta^{15} \mathrm{~N}$ measurements in particulate organic matter of natural and anthropogenic origin were used in a single isotope mixing model to elucidate the relative contributions of these sources to the isotopic $\mathrm{N}$ signal measured in epiphytes and leaf tissues. Total tissue $\mathrm{N}$ content was similar between meadow areas, but $\delta^{15} \mathrm{~N}$ signatures were significantly higher in the FA area than in the CA area both in epiphytes and seagrass leaf tissues. Results from the mixing model, together with available information on local currents and previous studies, support the conclusion that the dispersion of farm wastes over large areas (spanning kilometres) are responsible for the elevated $\delta^{15} \mathrm{~N}$ signatures found in the FA meadow area. Despite this, no changes in meadow structure were detected and only some changes at the level of seagrass community (epiphytes abundances and herbivores activity) could be interpreted at the light of nutrient-induced effects in the FA area. Results from this study indicate that concentrating aquaculture facilities in offshore areas is a strategy not totally exempt of environmental risk on nearshore sentitive habitats such as seagrass meadows.

Keywords: Fish farms waste; Posidonia oceanica; Epiphytes; Mediterranean Sea; Stable isotopes. 


\section{Introduction}

The increasing use of floating net cages in the Mediterranean Sea is a subject of major concern, due to the impact of farm waste on marine ecosystems (FAO, 2006). Floating net cages lead to considerable amounts of dissolved and particulate carbon, nitrogen and phosphorus contained in uneaten feed components, excreta and faeces being released into the water column (Hall et al., 1991, 1992; Holby and Hall 1991; Dosdat et al., 1995). By altering water quality and sediment characteristics (Holmer et al., 2007; Holmer and Kristensen 1992; Iwama 1991; Karakassis et al., 2001; Wu et al., 1994), these aquaculture inputs have been shown to affect both the functioning and structure of microbial (Vezzuli et al., 2002), planktonic (Pitta et al., 1999), infaunal (Karakassis et al., 2000; Mirto et al., 2002;) and seagrass (Apostolaki et al., 2009; Cancemi et al., 2003; Delgado et al., 1997;1999; Ruiz et al., 2001) communities in the Mediterranean coastal ecosystem.

Seagrass meadows are dominant habitats of recogized ecological relevance in temperate and tropical coastal areas (Green and Short, 2003), but they are experiencing a worldwide decline mainly associated to human activity (Orth et al., 2006). Net cage farming developed throughout the 1990s on the Spanish Mediterranean coast, with small fish farms (i.e. with an annual fish production of several hundred tons) installed in shallow, sheltered and semi-exposed environments where the endemic seagrass Posidonia oceanica forms dense and continuous meadows. In these low dispersive environments, high concentrations of dissolved nutrients and particulate (POM) and sedimentary (SOM) organic matter have led to the loss and deterioration of Posidonia oceanica meadows (Apostolaki et al., 2009; Cancemi et al., 2003; Delgado et al., 1997; Pergent et al., 1999; Pergent-Martini et al., 2006; Ruiz et al., 2001). This seagrass decline has been related to the effects of nutrient excess on plant physiology (Pérez et al., 2008), the toxic effects of sediment anoxia and high sulphide concentrations on plant tissues (Frederiksen et al., 2008; Pérez et al., 2007), and with nutrient-induced interactions between plants and other components of the seagrass community, such as macroalgae, epiphytes and herbivores (Delgado et al., 1997; Leoni et al., 2006; Ruiz et al., 2001; Ruiz et al., in press).

As a result of the limited availability of un-vegetated sheltered sites in nearshore environments and the continuous expansion of this aquaculture industry, it has been necessary to place farms in deeper $(>30 \mathrm{~m})$ offshore waters with mainly un-vegetated 
soft beds (Basurco and Larrazabal, 2000) in order to avoid further degradation of $P$. oceanica meadows. In these offshore environments, higher current speeds and greater depths should lead to a greater dispersion rate of farm waste and a reduction of SOM, with benthic communities underneath fish cages being affected less as a result (AguadoGiménez et al., 2007; Maldonado et al., 2005). However, this contention ignores the possible effects of dispersed farm waste on nearby seagrass communities. The influence of aquaculture waste over a large area has tended to be underestimated by previous studies based on traditional approaches involving only a physicochemical and biological characterization of seawater and sediments, which determine that the extent of the impact of fish farms is very local (no more than a few hundred metres), or even nonexistent (Aguado-Giménez et al., 2007; Cromey et al., 2002; Karakassis, 2001; Pearson and Black, 2000; Pitta et al., 1999; Pitta et al., 2006; Telfer and Beveridge, 2001). However, stable isotope techniques applied recently to trace the spatial extent of farm waste in water, sediment, benthic organisms and bioassays revealed that aquaculture products disperse to distances ranging between hundreds of metres and several kilometres (Dolenec et al., 2007; Jones et al., 2001; Lin and Fong, 2008; Sará et al., 2004; Sanz et al., in press; Vizzini and Mazzola, 2004; Ye et al., 1991). Therfore, the suitability of the "offshore strategy" to preserve nearshore Posidonia oceanica meadows against aquaculture waste has yet to be properly evaluated.

In this study, we combined the use of seagrass bioindicators, stable isotope techniques and spatial analysis to evaluate: (1) the remote influence on the Posidonia oceanica meadow of waste originated by an offshore fish farm complex, and (2) the impact of such an influence on the condition of the seagrass. To this end, we selected a set of Posidonia oceanica variables that have previously shown to effectively reflect both the influence and impact of farm waste at different levels of seagrass organization (Pérez et al., 2007; Ruiz et al., 2001): total and isotopic nitrogen content in epiphytes and seagrass leaf tissues, epiphyte biomass, shoot size, herbivory pressure, shoot density and meadow cover. We examined the null hypothesis that there are no differences in these variables between a meadow area in front of the fish farm facilities and an, unpolluted control area of meadow. A mixing model approach was also applied, using isotopic nitrogen signals obtained in epiphytes and seagrass leaves, to determine the specific contribution of farm waste with regard to other natural and anthropogenic POM sources. 
115 2. Materials and Methods

116

117

\subsection{Study area}

118 The study was conducted in a town on the southeast coast of Spain (San Pedro 119 del Pinatar; Murcia; $37^{\circ} 50^{\prime} 12.88^{\prime \prime} \mathrm{N}, 0^{\circ} 47^{\prime} 34.26^{\prime \prime}$ W. Fig. 1). A fish farm complex has 120 operated in the waters of this town since 1998, with a current total annual production of 1216.197 tons of blue fin tuna (Thunnus thynnus), sea bream (Sparus aurata), meagre 122 (Argyrosomus regius) and sea bass (Dicentrarchus labrax). Available data on current 123 speed and direction in the farming site taken over a six-month period (Sánchez-Lizaso, 124 unpubl. data) indicate that surface currents (7 $\mathrm{m}$ depth) most frequently run parallel to 125 the coastline in NW (34\%) and SW (25\%) directions, with an average speed of $10 \mathrm{~cm} \mathrm{~s}^{-}$ $126{ }^{1}$ and a maximum speed of $68 \mathrm{~cm} \mathrm{~s}^{-1}$. Deeper currents (25 m depth) run mainly in SE 127 (35\%) and NW (25\%) directions, with an average speed of $7 \mathrm{~cm} \mathrm{~s}^{-1}$, and a maximum 128 measured speed of $27 \mathrm{~cm} \mathrm{~s}^{-1}$. In this coastal area, the Posidonia oceanica meadow 129 forms a large and continuous band $25 \mathrm{~km}$ long (a total surface area of ca. $5.000 \mathrm{ha}$ ), 130 between $1 \mathrm{~m}$ and a mean depth limit of $27 \mathrm{~m}$ (Ruiz 2007; Fig. 1). Hydrodynamic 131 exposure and substrate type are similar throughout the whole meadow area. 132 Oceanographic characteristics (salinity, nutrients, light attenuation coefficient and Chl 133 a) correspond to typical high oligotrophic waters of this geographical area (Vargas134 Yáñez et al., 2007), except in the central area, due to the influence of hypersaline waters 135 of the Mar Menor coastal lagoon. A database of 90 sampling points available for this 136 meadow (Ruiz, unpubl. data) shows that the meadow structure is highly homogeneous

137 throughout this area, and corresponds to a healthy meadow in a good state of 138 conservation.

139

142 Posidonia oceanica meadow $(26-27 \mathrm{~m})$ in front of the fish farming area (hereinafter 143 'FA', Fig. 1). The nearest distance between the edge of the meadow and the fish cages 144 was $2.8 \mathrm{~km}$. At the time of the sampling (summer), Posidonia oceanica shoot and 145 epiphyte biomasses (Ruiz et al., 2001; Sánchez Lizaso 1993) were at their maximum, as 146 was fish production, with annual maximums of light and typical temperatures for the 147 time of year in the Mediterranean (Klein and Roether 2001). The FA meadow was 148 compared with a control meadow area (CA) $12.2 \mathrm{~km}$ in a southerly direction at the same 
149 depth, very close to the Marine Reserve of Cabo Palos-Islas Hormigas (Fig. 1). This control meadow area was selected due to its similarity with the FA meadow, and to rule out any possible influence of fish farm effluents, hypersaline waters from the coastal lagoon or any other anthropogenic influence. No alternative control sites could be found either northward, due to the influence of continental inputs, or to the south, due to the intense alteration of deep Posidonia oceanica meadows caused by illegal trawling over recent decades (Martín et al., 1997).

A nested sampling design (Quinn and Keough, 2002) was used to incorporate and partition spatial variability of the selected seagrass variables at the different spatial scales (from metres to kilometres) included in each meadow area. Two replicated locations, separated by approximately 1.5 kilometres, were selected in each meadow area (L1- L2 in FA and L3-L4 in CA, Fig. 1). Two sites separated by 100 metres were selected within each location. Meadow structure showed high patchiness in all sites, so three patches separated by a few metres were selected at random. For seagrass variables measured at the level of individual shoots (i.e. shoot size, epiphyte load, total $\mathrm{N}$ content and isotopic $\mathrm{N}$ signatures), six vertical shoots of Posidonia oceanica were randomly collected within each patch and transported to the laboratory for further measurement and analysis. At the patch level, the selected variables were shoot density and herbivore pressure. Shoot density (number of shoots per $\mathrm{m}^{-2}$ ) was measured by counting shoot numbers in $400 \mathrm{~cm}^{2}$ quadrants placed in six randomly selected patches within each site. In each site, herbivory pressure was determined in three randomly selected patches as the frequency (percentage) of leaves with recognizable marks of herbivores bites

171 (Boudouresque and Meinesz, 1982), relative to the total number of leaves contained in

17240 shoots collected within each patch. At the meadow level (i.e. sites), meadow cover

173 (as a percentage) was measured by visually estimating the percentage of substrate

174 occupied by shoot patches within twelve $1600 \mathrm{~cm}^{2}$ quadrants placed at regular intervals 175 along a $25 \mathrm{~m}$ line transect.

176 In order to determine the specific contributions of external, natural and 177 anthropogenic organic matter sources to the isotopic $\mathrm{N}$ signature measured in plant and 178 epiphytes tissues (see mixing model analysis below), POM was collected in six 179 replicated sediment traps deployed close to the net cages and in one site of the control 180 area (CA) over the seagrass canopy. POM samples at the first site were mainly 181 composed of fish faeces and hence we assume that they represent the external 182 anthropogenic source to be mainly farm waste (FFW); at the second site we assume that 
183 POM samples represent the external natural source (NAT) that is composed of a

184 mixture of both autochthonous and allochthonous materials of diverse origin (Dolenec 185 2006, Sarà 2006). Sediment traps consisted of PVC cylinders of $11 \mathrm{~cm}$ diameter and 55 $186 \mathrm{~cm}$ height, as recommended by many authors in similar studies (Cromey et al., 2002).

187 Trapped particles were concentrated in a small glass tube placed at the bottom end of 188 the cylinder, which was recovered after 24 hours and immediately transported to the 189 laboratory for analysis of stable isotopes (see below).

\subsection{Laboratory analysis}

In the laboratory, epiphytes were scraped and separated from the leaves of each shoot using a razor blade, and the epiphytes were dried to a constant weight $\left(60^{\circ} \mathrm{C}, 24\right.$ h) to estimate their biomass (mg DW shoot ${ }^{-1}$ ). The length and width of each leaf on a shoot were measured to calculate shoot size as leaf surface area per shoot $\left(\mathrm{cm}^{2} \operatorname{shoot}^{-1}\right)$; epiphyte biomass was normalized to shoot size to estimate epiphyte load $\left(\mathrm{mg} \mathrm{cm}^{-2}\right)$. Dried epiphyte and leaf tissues (young leaves, 0-50 days old) were finely grounded in a mortar and, for each replicate, approximately $2 \mathrm{mg}$ of dry weight was encapsulated to determine total $(\% \mathrm{DW})$ and isotopic $\left(\delta^{15} \mathrm{~N}, \%\right.$ ) nitrogen. POM samples obtained in sediment traps were filtered in laboratory through pre-combusted fibreglass filters (Whatman GF/F), and the filters were dried and ground for analysis of total and isotopic nitrogen. Total $\mathrm{N}$ content was measured using a Carlo-Erba $\mathrm{CNH}$ elemental autoanalyzer. The nitrogen stable isotope composition was measured using an EAIRMS (Thermo Finnigan) analyzer in continuous flow configuration, and was compared with a worldwide standard (atmospheric $\mathrm{N}_{2}$ ) to estimate the relative amount of ${ }^{15} \mathrm{~N}$, or $\delta^{15} \mathrm{~N}$ in plant tissues and POM, as described by the following equation (Peterson and

$\delta^{15} N(\%)=\left(R_{\text {sample }} / R_{\text {standard }}-1\right) \times 10^{3}$

208 where $R$ is defined as the atomic ${ }^{15} N^{/ 14} N$ ratio. Acetanilide was used as the internal 209 laboratory standard.

\subsection{Statistical analysis}

A nested ANOVA model was used to test the null hypothesis that seagrass

212 variables were similar across meadow areas, locations, sites and seagrass patches. For 
213 seagrass variables measured at the individual shoot level, a four-factor model was 214 considered: (1) "areas" (fixed factor with 2 levels: FA and CA), (2) "locations" (random 215 factor nested in "areas" with 2 levels: L1 and L2 in area FA and L3 and L4 in area CA), 216 (3) "sites" (random factor nested within each "location" with 2 levels) and (4) "patches" 217 (random factor nested within each "site" with 3 levels). For seagrass variables replicated 218 at site level (meadow cover, shoot density and herbivory pressure), a model with the 219 first three factors considered was used. Prior to the analysis, Cochran's C-test was used 220 to test the homogeneity of variances (Underwood, 1997), and data were properly 221 transformed when necessary. When no homogeneous variances were rendered with any 222 type of transformation, the significance level was set at 0.01 instead of 0.05 , as 223 ANOVA can withstand variance heterogeneity, particularly for large balanced experiments, reducing the possibility of a Type I error (Underwood, 1997).

A single-isotope three-source mixing model (Phillips and Gregg, 2003) was used to determine the relative contribution of farm sources in the isotopic $\mathrm{N}$ signature of epiphytes in relation to other potential external sources present in the study area. Epiphyte $\mathrm{N}$ signatures measured in FA and CA meadow areas were designated as the targets in the model. Seagrass leaf N signature was not included in this analysis, as it is governed not only by external water sources but also by internal physiological mechanisms and sediment pools (Romero et al., 2006; Touchette and Burkholder, 2000) that were not measured in this study. The isotopic signal of three potential sources were considered as the end-members of the model: fish farm waste (FFW), external natural sources (NAT), both of which were measured in this study (see previous section), and urban waste (UW), reported from literature $\left(\delta^{15} \mathrm{~N}=9.7 \%\right.$, Dolenec et al., 2007). This last external anthropogenic source was introduced into the model due to the presence of an urban sewage outfall $6 \mathrm{~km}$ north of the FA area.

\section{Results}

Table 1 shows the results of the nested ANOVA test on seagrass variables. Meadow cover varied between $14.5 \pm 3.4 \%$ and $27.0 \pm 2.4 \%$ (Fig. 2A), but no significant differences were detected between areas or at any other spatial scale within

244 them. Shoot density was also similar (116-200 shoots $\left.\mathrm{m}^{-2}\right)$ between areas and sites, with 245 the exception of the significant higher mean values founded in location L4 in the CA 246 meadow $\left(295.2 \pm 12.5\right.$ shoots $\left.\mathrm{m}^{-2}\right)$ (Fig. $2 \mathrm{~B}$; Table 1$)$. Herbivore pressure on seagrass 
247 leaves was generally very low $(0-7 \%)$, but showed highly significant variation between

248 locations due to the extremely high values measured in location L2 of the FA meadow 249 area (8.3-28\%; Fig. 2C and Table 1). This herbivore pressure was accounted for by the 250 herbivorous sparid fish Sarpa salpa in L2, but by other unidentified herbivore species 251 (possibly isopods) in the CA meadow locations.

252 Shoot size was slightly (but not significant) lower in the FA meadow (421.4 \pm $25317.8 \mathrm{~cm}^{2}$ shoot $\left.^{-1}\right)$ than in the CA meadow $\left(472.2 \pm 22.0 \mathrm{~cm}^{2} \operatorname{shoot}^{-1}\right)$; spatial variability 254 of this variable was only significant at the smaller scale i.e. between patches (Fig. 3A, 255 Table 1). Epiphyte load showed lower mean values in the FA area $(1.11 \pm 0.23 \mathrm{mg}$ DW $\left.256 \mathrm{~cm}^{-2}\right)$ than in the CA area $\left(1.77 \pm 0.14 \mathrm{mg} \mathrm{DW} \mathrm{cm}^{-2}\right.$ ) (Fig. 3B), but differences were not 257 significant at this and any other spatial scale (Table 1). Subsequent calculations of the observed power of the test for 'Area' effects (13.8\%) indicated a low capability to detect differences observed in epiphyte load (i.e. high probability of Type II error); the non-significant term 'Location' (Table 1) was then pooled to increase the power of the test after considering a conservative significance level of $\alpha=0.25$ for the pooled term (Sokal and Rohlf, 1995; Quinn and Keough, 2002). After pooling, the power of the test for the 'Area' effect on epiphyte load increased to $70 \%$, and significant differences in epiphyte load between areas were then detected $(\mathrm{df}=1,6 ; \mathrm{F}=10.29 ; \mathrm{P}=0.0184)$.

Mean epiphyte $\mathrm{N}$ content varied between 0.7 and $1.0 \%$ throughout the area studied with maximum values concentrated in the FA meadow, but no significant differences were detected at any spatial scale considered in the analysis (Fig. 3C, Table 1). Mean leaf $\mathrm{N}$ content varied between 1.4 and 1.9\% and was also similar between areas, but very significant variability was detected between locations and seagrass patches (Fig. 3E, Table 1). The isotopic signal of nitrogen $\left(\delta^{15} \mathrm{~N}\right)$ in epiphyte tissues was consistently and significantly higher in the FA meadow $(5.36 \pm 0.013 \%$ ) than the CA meadow $(3.75 \pm 0.013 \%$ o) (Fig. 3D, Table 1). Variability between localities within each meadow area was also significant for this variable (SNK, Table 1). Isotopic nitrogen

274 measured in seagrass leaves also showed significantly higher mean values in the FA meadow $(3.69 \pm 0.02 \%)$ than at CA $(2.98 \pm 0.08 \%)($ Fig. $3 F)$, although the variability between seagrass patches within sites was also significant (Table 1). significant differences between FFW and NAT sources, with higher values for the former $(6.67 \pm 0.32 \%)$ than for the latter $(3.69 \pm 0.17 \%)(n=6$; t-test, $\mathrm{p}<0.05)$.

280 Table 2 shows the results of the mixing model applied to determine the relative 
281 contributions of distinct isotopic $\mathrm{N}$ signatures measured in various sources to the mixed

$282 \mathrm{~N}$ signature measured in epiphytes. For each meadow area, the table indicates the range

283 (1- 99th percentile) and the mean and standard deviation of the distribution of all 284 feasible contributions from each source to the epiphyte $\mathrm{N}$ signature. In the FA area, fish 285 farm waste $(\mathrm{FFW}=12-56 \%)$ and natural sources (NAT $=44-66 \%)$ both provided the 286 most significant contributions to the epiphytes $\mathrm{N}$ signature. The contribution of urban 287 waste was very low and ambiguous, since it included zero contributions ( $U W=0-22 \%$ ). 288 In the CA area, epiphyte $\mathrm{N}$ signal was unambiguously accounted by external natural 289 sources $($ NAT $=98-99 \%)$ while external anthropogenic contributions (FFW and UW) 290 were almost negligible (0-2\%).

\section{Discussion}

Both epiphytes and seagrass leaf tissues were particularly and significantly ${ }^{15} \mathrm{~N}$ enriched in Posidonia oceanica plants located $3 \mathrm{~km}$ from the fish farm complex (i.e. the FA meadow area) in comparison with the control meadow, which seems to reflect the nature of external $\mathrm{N}$ sources influencing each meadow area. In the control meadow area, POM (NAT source) had an isotopic $\mathrm{N}$ signal similar to that measured in water samples from unpolluted natural sites in near-shore Mediterranean environments (2-4\%o, e.g.

300 Dolenec et al., 2007; Sará et al., 2004). It may therefore represent a natural or 301 "background" signal composed by a mixture of detritus material of marine and terrestrial origin, phyto- and zooplankton (Dolenec et al., 2007), and, in this case, seagrass detritus. By contrast, POM collected close to the fish cages (FFW) consisted mostly of uneaten food pellets and fish faeces, and exhibited higher positive $\delta{ }^{15} \mathrm{~N}$ values as those typically measured in these anthropogenic sources (6-11\%o, e.g. Dolenec

306 et al., 2007; Sará et al., 2004). In the water column, rapid mineralization of this initially

307 N-enriched POM results in an impoverishment of its isotopic $\mathrm{N}$ signature and an 308 enrichment in the dissolved $\mathrm{N}$ pool, due to isotopic fractionation by physical and 309 biological process (Macko and Ostrom, 1994; Sará et al., 2004). Excreta from farmed 310 fish (Dosdat et al., 1995) and wild fish around the cages (Fernández-Jover et al., 2008), 311 as well as re-suspension of enriched SOM (Sará et al., 2006), contribute significantly to 312 this dissolved ${ }^{15} \mathrm{~N}$-enriched pool, which currents immediately disperse toward 313 surrounding areas (Sarà et al., 2004, 2006). 
The isotopic $\mathrm{N}$ composition of benthic primary producers reflected that of external $\mathrm{N}$ sources (Fry, 2006). High $\delta^{15} \mathrm{~N}$ values, such as those observed in epiphytes and seagrass tissues in the FA meadow, are associated with the influence of external anthropogenic sources such as aquaculture loads and land-derived wastewater (Cole et 318 al., 2004; Cole et al., 2005; Constanzo et al., 2001; Constanzo et al., 2004; Dolenec et 319 al., 2007; Jones et al., 2001; Lin and Fong, 2008; Pérez et al., 2008; Vizzini and 320 Mazzola, 2004). Several findings support this hypothesis in our case study: (1) fish farm 321 production in our study was approximately 4.2 times higher than a case study that recorded elevated $\delta{ }^{15} \mathrm{~N}$ signatures in Posidonia oceanica leaves over an area located up to $3 \mathrm{~km}$ from the fish farm (Dolenec et al. 2007); (2) the dominant current direction was NW (34\%), but the frequency of currents directed toward the FA meadow area (i.e. SW) was also important (25\%); (3) the mean velocity of SW currents was $10 \mathrm{~cm} \mathrm{~s}^{-1}$ and reached maximum values of $58 \mathrm{~cm} \mathrm{~s}^{-1}$, which has shown to be enough to disperse farm waste over a distance covering several kilometres (Sará et al., 2006); (4) a spatial gradient of $\delta{ }^{15} \mathrm{~N}$ between the fish farm and the FA meadow area was obtained in a previous study by measuring isotopic $\mathrm{N}$ in benthic macrophytes incubated in pelagic bioassays deployed at increasing distances from fish cages (García-Sanz et al., in press); and finally, (5) the mixing model used in this study provided consistent evidence of the significant contribution of farm waste (i.e. FFW source) to the isotopic $\mathrm{N}$ signature of epiphyte tissues in the FA meadow area. Therefore we can consider that farm waste is responsible for the high $\delta{ }^{15} \mathrm{~N}$ signatures measured in the seagrass and epiphyte tissues of the FA meadow located $2.8 \mathrm{~km}$ from the aquaculture facilities.

With a high availability of nutrients, seagrass and its epiphytes can assimilate and store excess nutrients in their tissues, increasing their total $\mathrm{N}$ content (Lepoint et al., 2007; Invers et al., 2004; Touchette and Burkholder, 2000). However, no significant increase in nitrogen was observed in either Posidonia oceanica leaves or epiphytes in the FA meadow, despite the influence of farm waste. A possible explanation is that the

341 nutrients supplied are too low to merit long-term $\mathrm{N}$ storage, and are probably used to sustain growth, as suggested for macroalgae species exposed to moderate nutrient increase in fertilization experiments (McGlathery, 1995) and from shrimp farm loads

344 (Lin and Fong, 2008). This argument can be particularly valid for epiphytic algae, 345 which quickly exploit any increase in water column nutrient availability (Lepoint et al., 346 2007; Short et al., 1995). Furthermore, nutrients could favour opportunistic epiphytic 347 algae over seagrass leaves (Duarte, 1995; McGlathery et al., 1995; Prado et al., 2008; 
348 Wear et al., 1999), the rapid growth of which prevents $\mathrm{N}$ accumulation in their tissue.

349 Nonetheless, epiphytes showed greater variability of $\mathrm{N}$ content between seagrass 350 patches within some of the FA meadow sites, as a consequence of the maximum values 351 obtained only in this meadow area (Fig. 3C), which can be interpreted as a 352 heterogeneous influence of farm waste on epiphyte $\mathrm{N}$ content at a small spatial scale. In 353 seagrass leaves, the lack of $\mathrm{N}$ response to water-dissolved nutrients has a more complex 354 interpretation, as it can also be governed by other limiting factors (e.g. light), 355 competition for nutrients by epiphytes, internal $\mathrm{N}$ and $\mathrm{C}$ metabolism and sediment 356 nutrient pools (Invers et al., 2004; Romero et al., 1998; Romero et al., 2006; Touchette and Burkholder, 2000).

358 In response to fish farm load, epiphyte abundance in Posidonia oceanica leaves can either rise (Cancemi et al., 2003; Delgado et al., 1997, 1999) or decrease due to enhanced consumption of epiphyted leaf tips by seagrass macro-herbivores (Ruiz et al., 2001; Ruiz, 2000; Ruiz et al., in press). Previous experimental studies support the existence of this nutrient-macrograzers interaction in $P$. oceanica meadows (Prado 2007; Ruiz, 2000) and in tropical seagrass communities (McGlathery, 1995; Goecker et al., 2005). However, our data did not support the existence of such interaction in the FA meadow since the spatial pattern showed by the herbivorous fish $S$. salpa activity was not coupled with that of epiphyte abundance (Figs. 2C and 3B, respectively).

367 Alternatively, we suggest that nutrient induced changes in the composition of the epiphytic assemblage and/or enhanced mesoherbivores (mainly gastropods) activity

369 (Lin et al., 1996, see Borowitzka et al., 2006, Valentine and Duffy, 2006 Burkholder et 370 al 2007 for a recent review of this topic) might also account for the reduction in 371 epiphyte abundance reported in the FA meadow. Nonetheless, since no measurements 372 of these variables are available this possibility is speculative and other factors must be 373 considered including those responsible for natural spatial patterns of $P$. oceanica 374 epiphyte assemblages (e.g. Balata et al., 2007; Pardi et al., 2006). Apart from these 375 possible changes in seagrass community, no other evidence of any nutrient-related 376 effect was obtained at the level of meadow structure. Smaller shoot size and altered 377 meadow structure (shoot density and meadow cover) are commonly reported responses 378 for Posidonia oceanica meadows directly exposed to aquaculture loads (e.g. Delgado et 379 al., 1997; Ruiz et al., 2001) or experimental nutrient enrichment (Leoni et al., 2006), 380 though this kind of alteration was not detected in our study. 
In conclusion, results based on stable isotope analysis, together with available

382 information on hydrodynamics and from previous studies in the study site, provide

383 consistent evidence that waste delivered by offshore farms has a large area of influence

384 (spanning kilometres) that affects Posidonia oceanica meadows located in remote near-

385 shore environments. Results obtained also indicate that such influence was not

386 sufficient to produce significant meadow alterations, unlike those described in near-

387 shore case studies under a more severe influence of nutrients. Only changes in the

388 abundance of epiphytes (and possibly in the activity of grazers) could be interpreted in

389 the light of nutrient-induced effects at the community level, but further evidence would

390 be required to confirm it. Finally, based on this study case, the idea that concentrating

391 aquaculture facilities in offshore areas is a strategy totally exempt of environmental risk

392 cannot be supported and hence site-selection processes for new aquaculture facilities

393 must be careful with regard to the distribution of this and other sensitive habitats, even

394 when these are located at distances greater than one kilometre.

395

396 Acknowledgments

397 This study is a part of a project funded by the Plan Nacional de Cultivos Marinos of the

398 Junta Nacional Asesora de Cultivos Marinos (JACUMAR) to JMR during the period

399 2004-2007. We would like to thank IEO technician Rocío García Muñoz for her

400 valuable help in laboratory work and field sampling. JMR would like to thank TAXON

401 Estudios Ambientales S.L. and the students Teresa Castro and Eva Vázquez for field

402 assistance. We acknowledge to the Servizos de Apoio à Investigación of the University

403 da Coruña for their support in the analysis of stable isotopes.

404 
405

406

407

408

409

410

411

412

413

414

415

416

417

418

419

420

421

422

423

424

425

426

427

428

429

430

431

432

433

434

435

436

437

\section{References}

Aguado-Giménez, F., Marín, A., Montoya, S., Marín-Guirao, L., Piedecausa, A. \& García-García, B. 2007. Comparisons between some procederes for monitoring off-shore cage culture in Western Mediterranean Sea: sampling methods and impact indicators in soft substrata. Aquaculture 271:357-370.

Apostolaki, E.T., Marbà, N., Holmer, M., Karakassis, I., 2009. Fish farming enhances biomass and nutrient loss in Posidonia oceanica (L.) Delile. Estuarine, Coastal and Shelf Science 81 (3), 390-400.

Balata, D., Nesti, U., Piazzi, L., Cinelli, F., 2007. Patterns of spatial variability of seagrass epiphytes in the north- west Mediterranean Sea. Marine Biology 151, 20025-2035.

Balestri, E., Cinelli, F., Lardicci, C., 2003. Spatial variation in Posidonia oceanica structural, morphological and dynamic features in a north-western Mediterranean coastal area: a multi-scale analysis. Marine Ecology Progress Series 250, 51-60.

Basurco, B., Larrazabal, G., 2000. Marine fish farming in Spain. Cahiers options méditerranéennes $30,45-56$.

Borowitzka, M.A., Lavery, P., Van Keulen, M., 2006. Epiphytes of seagrasses, in: Larkum, A.W.D., Orth, R.J., Duarte, C.M. (Eds.), Seagrasses: biology, ecology and conservation. Springer, The Netherlands, pp. 441-461.

Boudouresque, C.F., Meinesz, A., 1982. Découverte de l'herbier de Posidonies. Cahier du Parc National de Port-Cros, Hyères, France 4, 1-79.

Burkholder, J.M., Tomasko, D.A., Touchette, D.W., 2007. Seagrass and eutrophication. Journal of Experimental Marine Biology and Ecology 350, 46-72

Cancemi, G., De Falco, G., Pergent, G., 2003. Effects of organic matter input from a fish farming facility on a Posidonia oceanica meadow. Estuarine, Coastal and Shelf Science 56, 961-968.

Cinelli, F., Cormaci, M., Furnari, G., Mazella, L., 1984. Epiphytic macroflora of Posidonia oceanica (L) Delile leaves around the Island of Ischia (Gulf of Napoles), in: Boudouresque, C.F., Jeudy de Grissac, A., Olivier, J. (Eds), International Workshop on Posidonia oceanica beds. GIS Posidonie Publishers, Marseille, France, pp.91-99. 
438 Cole, M.L., Kroeger, K.D., McClelland, J.W., Valiela, I., 2005. Macrophytes as

439 indicators of land-derived wastewater: Application of a $\delta^{15} \mathrm{~N}$ method in aquatic systems. Water Resources Research 41, W01014.

Cole, M.L., Valiela, I., Kroeger, K.D., Tomasky, G.L., Cebrian, J., Wigand, C., 442 McKinney, R.A., Grady, S.P., Carvalho da Silva, M.H., 2004. Assessment of a $\delta$ $443{ }^{15} \mathrm{~N}$ isotopic method to indicate anthropogenic eutrophication in aquatic 444 ecosystems. Journal of Environmental Quality 33, 124-132.

445 Costanzo, S.D., O’Donohue, M.J., Dennison, W.C., Loneragan, N.R., Thomas, M., 446 2001. A new approach for detecting and mapping sewage impacts. Marine $447 \quad$ Pollution Bulletin 42(2), 149-156.

448 Costanzo, S.D., O'Donohue, M.J., Dennison, W.C., 2004. Assessing the influence and distribution of shrimp pond effluent in a tidal mangrove creek in north-east Australia. Marine Pollution Bulletin 48, 514-525.

Cromey, C., Nickell, T.D., Black, K.D., 2002. DEPOMOD-modelling the deposition and biological effects of waste solids from marine cage farms. Aquaculture 214, 211-239.

Delgado, O., Grau, A., Pou, S., Riera, F., Massuti, C., Zabala, M. and Ballesteros, E., 1997. Seagrass regression caused by fish cultures in Fornells Bay (Menorca, Western Mediterranean). Oceanologica Acta 20, 557-563.

Delgado, O., Ruiz, J.M., Pérez, M., Romero, J., Ballesteros, E., 1999. Effects of fish farming on seagrass (Posidonia oceanica) in a Mediterranean bay: seagrass decline after organic loading cessation. Oceanologica Acta 22(1), 109-117.

Dolenec, T., Lojen, S., Kniewald, G., Dolenec, M., Rogan, N., 2007. Nitrogen stable isotope composition as a tracer of fish farming in invertebrates Aplysina aerophoba, Balanus perforatus and Anemonia sulcata in the central Adriatic. Aquaculture 262, 237-249.

Dosdat, A., Gaumet, F., Chartois, H., 1995. Marine aquaculture effluent monitoringmethodological approach to the evaluation of nitrogen and phosphorus excretion by fish. Aquacultural Engineering 14, 59-84.

Duarte, C.M. 1995. Submerged aquatic vegetation in relation to different nutrient 468 regimes. Ophelia 41:87-112.

469 FAO, 2006. The State of World Fisheries and Aquaculture. FAO Fisheries and 470 Aquaculture Department. Food and Agriculture Organization of the United Nations, $471 \quad$ Rome, 2007. 
472 Fernández-Jover, D., Sánchez-Jérez, P., Bayle-Sempere, J., Valle, C., Dempster, T., 473 2008. Seasonal patterns and diets of wild fish assemblages with Mediterranean

474

475

476

477

478

479

480

481

482

483

484

485

486

487

488

489

490

491

492

493

494

495

496

497

498

499

500

501

502

503

504

505 coastal fish farms. ICES Journal of Marine Science 65 (7), 1153-1160.

Fong, C.V., Lee, S.Y., Wu, R.S., 2000. The effects of epiphytic algae and their grazers on the intertidal seagrass Zostera japonica. Aquatic Botani 67, 251-261.

Frederiksen, M.S., Holmer, M., Pérez, M., Invers, O., Ruiz, J.M., Knudsen, B.B., 2008. Effect of increased sediment sulphide concentrations on the composition of stable sulphur isotopes $\left(\delta^{34} \mathrm{~S}\right)$ and sulphur accumulation in the seagrasses Zostera marina and Posidonia oceanica. Journal of Experimental Marine Biology and Ecology 358, 98-109.

Fry, B., 2006. Stable Isotope Ecology. Springer, Science Business Media, USA, 308 pp. García-García, B., 2007. Comparison between some procedures for monitoring offshore cage culture in western Mediterranean Sea: sampling methods and impact indicators in soft substrata. Aquaculture 271, 357-370.

Goecker, M.E., Heck Jr, K.L., and Valentine, J.F., 2005. Effects of nitrogen content in turtlegrass, Thalassia testudinum, on consumption by the bucktooth parrotfish, Sparisoma radians. Marine Ecology Progress Series 286, 239-248.

Green, E.P., Short, F.T., 2003. World atlas of seagrasses. UNEP World Conservation Monitoring Centre, University of California Press, Berkeley, USA.. 298 pp.

Hall, P.O.J., Anderson, L.G., Holby, O., Kollberg, S., Samuelson, M., 1991. Chemical fluxes and mass balances in a marine fish cage farm. I. Carbon. Marine Ecology Progress Series 61, 61-73.

Hall, P.O.J., Holby, O., Kollberg, S., Samuelsson, M.O., 1992. Chemical fluxes and mass balances in a marine fish cage farm: IV. Nitrogen. Marine Ecology Progress Series 89, 81-91.

Holby, O., Hall, P.O.J., 1991. Chemical fluxes and mass balances in a marine fish cage farm. II. Phosphorus. Marine Ecology Progress Series 70, 263-272.

Holmer, M., Kristensen, E., 1992. Impact of marine fish cage farming on sediment metabolism and sulphate reduction of underlying sediments. Marine Ecology Progress Series 80, 191-201.

Holmer, M., Marba, N., Díaz-Almela, E., Duarte, C.M., Tsapakis, M., Danovaro, R., 2007. Sedimentation of organic matter from fish farms in oligoptrophic Mediterranean assessed through bulk and stable isotope $\left(\delta^{13} \mathrm{C}\right.$ and $\left.\delta^{15} \mathrm{~N}\right)$ analyses. Aquaculture 262, 268-280. 
506

507

508

509

510

511

512

513

514

515

516

517

518

519

520

521

522

523

524

525

526

527

528

529

530

531

532

533

534

535

536

537

538

539

Invers, O., Kraemer, G.P., Pérez, M., Romero, J., 2004. Effects of nitrogen addition on nitrogen metabolism and carbon reserves in the temperate seagrass Posidonia oceanica. Journal of Experimental Marine Biology and Ecology 303 (1), 97-114.

Iwama, G.K,. 1991. Interactions between aquaculture and the environment. Critical reviews in Environmental Conservation 21, 177-216.

Jones, A.B., O'Donohue, M.J., Udy, J., Dennison, W.C., 2001. Assessing ecological impacts of shrimp and sewage effluent: biological indicators with standard water quality analyses. Estuarine, Coastal and Shelf Science 52, 91-109.

Karakassis, I., Tsapakis, M., Astillan, E., Pitta, P., 2001. Diel variation of nutrients and chlorophyll in the sea bream and sea bass cages in the Mediterranean. Fresenius Environmental Bulletin 10, 278-283.

Karakassis, M., Tsapakis, I., Hatziyanni, E., Papadopoulou, K.N., Plaiti, W., 2000. Impact of cage farming of fish on seabed in three Mediterranean coastal areas. ICES Journal of Marine Science 57, 1462-1471.

Klein, B., Roether, W., 2001. Oceanografía y régimen hidrológico, in: El Mar Mediterráneo I. parte general, R. Hofrichter (Coord.), Ed. Omega, Barcelona, Spain, pp 258-287.

Leoni, V., Pasqualini, V., Pergent-Martini, C., Vela, A.., Pergent, G., 2006. Morphological responses of Posidonia oceanica to experimental nutrient enrichment of the canopy water. Journal of Experimental Marine Biology and Ecology 339, 1-14.

Lepoint, G., Jacquemart, J., Bouquegneau, J.M., Demoulin, V., Gobert, G., 2007. Field measurements of inorganic nitrogen uptake by epiflora components of the seagrass Posidonia oceanica (Monocotyledons, Posidoniaceae). Journal of Phycology 43, 208-218.

Lin, D.T., Fong, P., 2008. Macroalgal bioindicators (growth, tissue N, $\delta^{15} \mathrm{~N}$ ) detect nutrient enrichment from shrimp farm effluent entering Opunohu Bay, French Polynesia. Marine Pollution Bulletin 56 (2), 245-249.

Lin, H.J., Nixon, S.W., Taylor, D.I., Granjer, S.L., Buckley, B.A., 1996. Responses of epiphytes on eelgrass, Zostera marina L., to separate and combined nitrogen and phosphorus enrichment. Aquatic Botany 52, 243-258.

Macko, S.A., Ostrom, N.E., 1994. Pollution Studies Using Stable Isotopes, in: Lajtha, K., Michener, R.H. (Eds), Stable Isotopes in Ecology and Environmental Science, Blackwell Scientific Publications, Oxford, pp. 45-62. 
540

541

542

543

544

545

546

547

548

549

550

551

552

553

554

555

556

557

558

559

560

561

562

563

564

565

566

567

568

569

570

571

572

573

Maldonado, M., Carmona, M.C., Echeverría, Y., Riesgo, A. 2005. The environmental impact of Mediterranean cages fish farms at semi-exposed locations: does it need a re-assessment? Helgoland Marine Research 59, 121-135.

Martín, M.A., Sánchez Lizaso, J.L., Ramos Esplá, A.A., 1997. Cuantificación del impacto de las artes de arrastre sobre la pradera de Posidonia oceanica (L.) Delile Publ. Especiales del Instito Español de Oceanografía 23, 245- 255.

McGlathery, K.J., 1995. Nutrient and grazing influences on a tropical seagrass community. Marine Ecology Progress Series 122, 239-252.

Mirto, S., La Rosa, T., Gambi, C., Danovaro, R., Mazzola, A., 2002. Nematode community response to fish-farm impact in the western Mediterranean. Environmental Pollution 116, 203-214.

Orth, R.J., Carruthers, T.J.B., Dennison, W.C., Duarte, C.M., Fourqurean, J.W., Heck Jr, K.L., Hughes, A.R., Kendrick, G., Kenworthy, W.J., Olyarnik, S., Short, F.T., Waycott, M., Williams, S.L., 2006. A global crisis for seagrass ecosystems. BioScience 56(12), 987-996.

Pardi, G., Piazzi, L., Balata, D., Papi, I., Cinelli, F., Benedetti-Cecchi., L., 2006. Spatial variability of Posidonia oceanica (L.) Delile epiphytes around the mainland and the islands of Sicily (Mediterranean Sea). Marine Ecology 27, 397-403.

Pearson, T.H., Black, K.D., 2000. The environmental impacts of marine fish cage culture, in: Black, K.D. (Ed), Environmental impacts of aquaculture, Sheffield Academic Press, Sheffield, pp.1-31.

Pérez, M., García, T., Ruíz, J.M., Invers, O., 2008. Physiological responses of the seagrass Posidonia oceanica as indicators of fish farm impact. Marine Pollution Bulletin 56, 869-879.

Pérez, M., Invers, O., Ruiz, J.M., Frederiksen, M.S., Holmer, M., 2007. Physiological responses of the seagrass Posidonia oceanica to elevated organic matter content in sediments: an experimental assessment. Journal of Experimental Marine Biology and Ecology 344, 149-160.

Pergent, G., Mendez, S., Pergent-Martini, C., Pasqualini, V., 1999. Preliminary data on the impact of fish farming facilities on Posidonia oceanica meadows in the Mediterranean. Oceanologica Acta 22, 95-107.

Pergent-Martini, C., Boudouresque, C.F., Pasqualini, V., Pergent, G., 2006. Impact of fish farming facilities on Posidonia oceanica meadows: a review. Marine Ecology 27, 310-319. 
574

575

576

577

578

579

580

581

582

583

584

585

586

587

588

589

590

591

592

593

594

595

596

597

598

599

600

601

602

603

604

605

606

607

Peterson, B. J., Fry, B., 1987. Stable isotopes in ecosystem studies. Annual Review of Ecology and Systematics 18, 293-320.

Phillips, D.L., Gregg., J.W., 2003. Source partitioning using stable isotopes: coping with too many sources. Oecologia 136, 261-269.

Pitta, P., Apostolaki, E.T., Tsagaraki, T., Tsapakis, M., Karakassis, I., 2006. Fish farming effects on chemical and microbial variables of the water column: a spatiotemporal study along the Mediterranean Sea. Hydrobiology 563, 99-108.

Pitta, P., Karakassis, I., Tsapakis, M., Zivanovic, S., 1999. Natural vs. Mariculture induced variability in nutrients and plankton in the Eastern Mediterranean. Hydrobiology 391, 181-194.

Prado, P., 2007. Magnitude of herbivory in Posidonia oceanica and factors responsible for spatial variation. $\mathrm{PhD}$ thesis, University of Barcelona.

Prado, P., Alcoverro, T., Romero, J., 2008. Seasonal response of Posidonia oceanica epiphyte assemblages to nutrient increase. Marine Ecology Progress Series 359, 8998.

Quinn, G., Keough., M.J., 2002. Experimental design and data analysis for biologists. Cambridge University Press, Cambridge, UK, 527 pp.

Romero J, Pérez, M., Alcoverro, T., Mateo, M.A., Sánchez-Lizaso, J.L., 1998. Production ecology of Posidonia oceanica (L.) Delile meadows in Nueva Tabarca Marine Reserve: Growth biomass and nutrient stocks along a bathymetric gradient Oecologia Aquatica 11, 111-121

Romero, J., Lee, S.S., Pérez, M., Mateo, M.A. Alcoverro, T., 2006. Nutrient dynamics in seagrass ecosystems, in... Larkum, A.W.D., Orth, R.J., and Duarte, C.M. (Eds.), Seagrasses: biology, ecology and conservation, Springer, Netherlands, pp. 227-254

Ruiz, J.M., 2000. Respuesta de la fanerógama marina Posidonia oceanica (L.) Delile a perturbaciones antrópicas, $\mathrm{PhD}$ thesis, University of Murcia, Spain, $212 \mathrm{pp}$.

Ruiz, J.M., Pérez, M., Romero, J., 2001. Effects of fish farm loadings on seagrass (Posidonia oceanica) distribution, growth and photosynthesis. Marine Pollution Bulletin 42, 749-760.

Sánchez-Lizaso, J. L. 1993. Estudio de la pradera de Posidonia oceanica (L.) Delile de la Reserva Marina de Tabarca (Alicante): Fenología y producción primaria, Ph. D. Thesis, University of Alicante $130 \mathrm{pp}$.

Sarà, G., Scilipoti, D., Mazzola, A., Modica, A., 2004. Effects of fish farming waste to sedimentary and particulate organic matter in a southern Mediterranean area (Gulf 
608

609

610

611

612

613

614

615

616

617

618

619

620

621

622

623

624

625

626

627

628

629

630

631

632

633

634

635

636

637

638

639

640

of Castellamare, Sicily): a multiple stable isotope study $\left(\delta^{13} \mathrm{C}\right.$ and $\left.\delta^{15} \mathrm{~N}\right)$. Aquaculture 234, 199-213.

Sarà, G., Scilipoti, G., Milazzo, M., Modica, A., 2006. Use of stable isotopes to investigate dispersal of waste from fish farms as a function of hydrodynamics. Marine Ecology Progress Series 313, 261-270.

Short, F.T., Burdick, D.V., 1995. Mesocosm experiments quantify the effects of eutrophication on eelgrass, Zostera marina. Limnology and Oceanography 40, 740794.

Sokal, R. R., Rohlf, F. J., 1995. Biometry: The Principles and Practice of Statistics in Biological Research, 3 edition, Freeman, W.H. and Company (Eds.), New York, $880 \mathrm{pp}$.

Telfer, T.C., Beveridge, M.C.M., 2001. Monitoring environmental effects of marine fish aquaculture. Cahiers Options Méditerranéennes 55, 75-83.

Touchette, B.W., Burkholder, J.M., 2000. Review of nitrogen and phosphorus metabolism in seagrasses. Journal of Experimental Marine Biology and Ecology 250, 133-167.

Underwood, A.J., 1997. Experiments in ecology. Their Logical and Interpretation Using Analysis of Variance. Cambridge University Press, 504 pp.

Valentine, J.F. , Duffy, J.E., 2006. The central role of grazing in seagrass ecology, in: Larkum, A.W.D., Orth, R.J., Duarte C.M. (Eds.), Seagrasses: biology, ecology and conservation, Springer, The Netherlands, pp. 463-501.

Vargas-Yáñez, M., García-Martínez, M.C., Moya-Ruiz, F., Tel, E., Parrilla, G., FraileNuez, E., Lavín, A., 2007. Cambio climático en el Mediterráneo español. Instituto Español de Oceanografía, Madrid. Temas de Oceanografía 1, 169 pp.

Vezzuli, L., Chelosi, E., Riccardi, G., Fabiano, M., 2002. Bacterial community structure and activity in fish farm sediments of the Ligurian Sea (Western Mediterranean). Aquaculture International 10, 123-141.

Vizzini, S., Mazzola, A., 2004. Stable isotope evidence for the environmental impact of a land-based fish farm in the western Mediterranean. Marine Pollution Bulletin 49, $61-70$.

Wear, D.J., Sullivan, M.J., Moore, A.D., Millie, D.F., 1999. Effects of water column enrichment on the production dynamics of three seagrass species and their epiphytic algae. Marine Ecology Progress Series 179, 201-213. 
641 Wu, R.S.S., Lam, K.S., Mackay, D.W., Lau, T.C., Yam, V., 1994. Impact of marine fish 642 farming on water quality and bottom sediment: a case study of the sub-tropical 643 environment. Marine Environmental Research 38, 115-145.

644 Ye, L.X., Ritz, D.A., Fenton, G.E., Lewis, M.E., 1991. Tracing the influence on 645 sediments of organic waste from a salmon farm using stable isotope analysis. 646 Journal os Experimental Marine Biology and Ecology 145,161-174. 
$647 \quad$ Figure Captions

648

649 Figure 1. Map of the study area indicating the location of the fish farms (empty

650 polygons) and sampled meadow areas (see the Materials and Methods section).

651

652 Figure 2. Mean \pm SE of $\mathbf{A}$ the percentage of meadow cover; $\mathbf{B}$ the shoot density (shoots

$653 \mathrm{~m}^{-2}$ ); and $\mathbf{C}$ herbivore pressure (\% of leaves eaten) at sites sampled within each location. 654

655 Figure 3. Mean \pm SE of $\mathbf{A}$ the shoot size (as leaf surface area, $\mathrm{cm}^{2}$ shoot $^{-1}$ ); $\mathbf{B}$ epiphyte 656 load ( $\left.\mathrm{mg} \mathrm{DW} \mathrm{cm}^{-2}\right)$; C epiphyte $\mathrm{N}$ content (\% DW); D epiphyte isotopic nitrogen

$657\left(\delta^{15} \mathrm{~N}\right) ; \mathbf{E}$ leaf $\mathrm{N}$ content (\% DW); and $\mathbf{F}$ leaf isotopic nitrogen composition $\left(\delta^{15} \mathrm{~N}\right)$. 
$14 \quad$ Figure 1

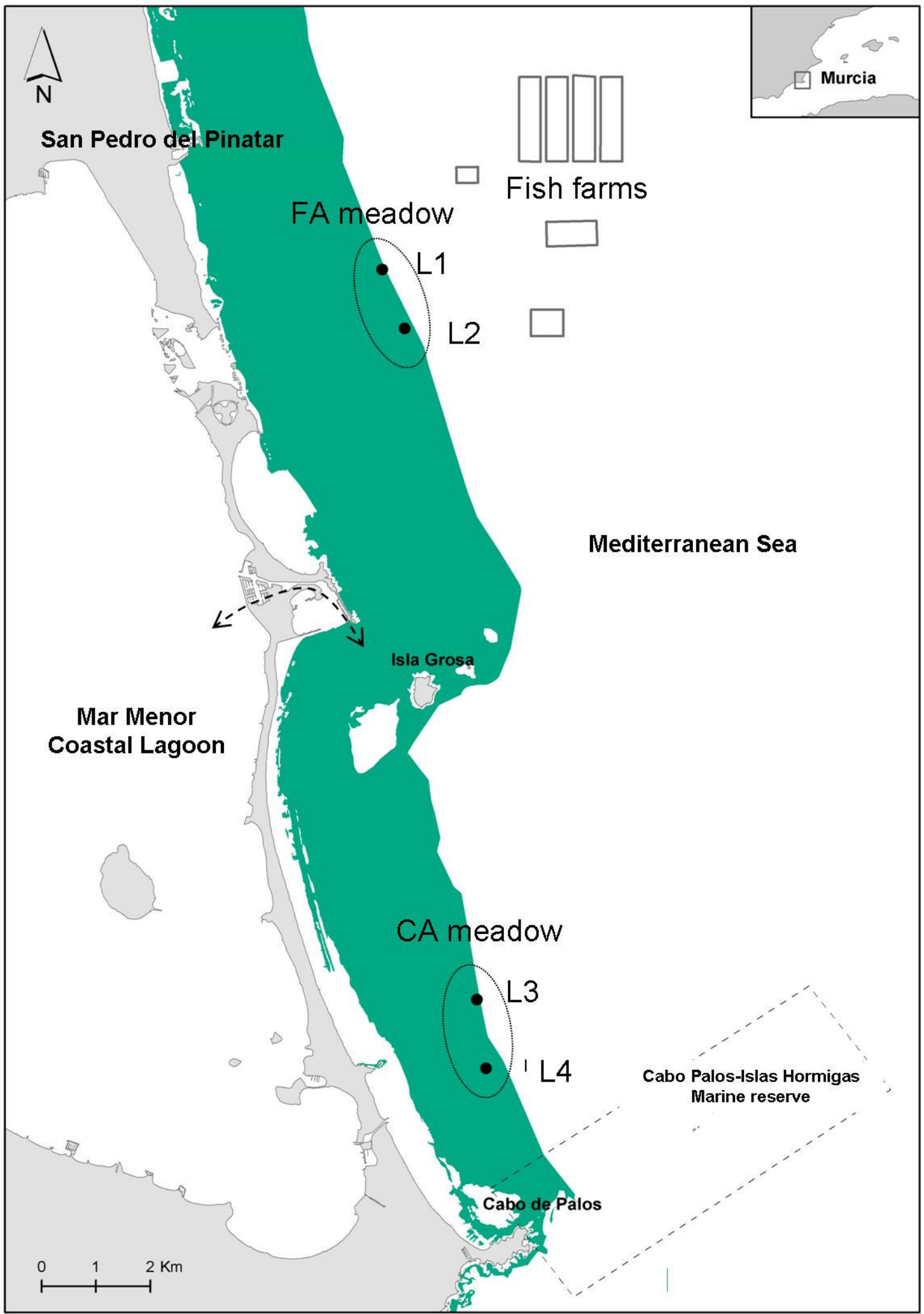


Figures 2:
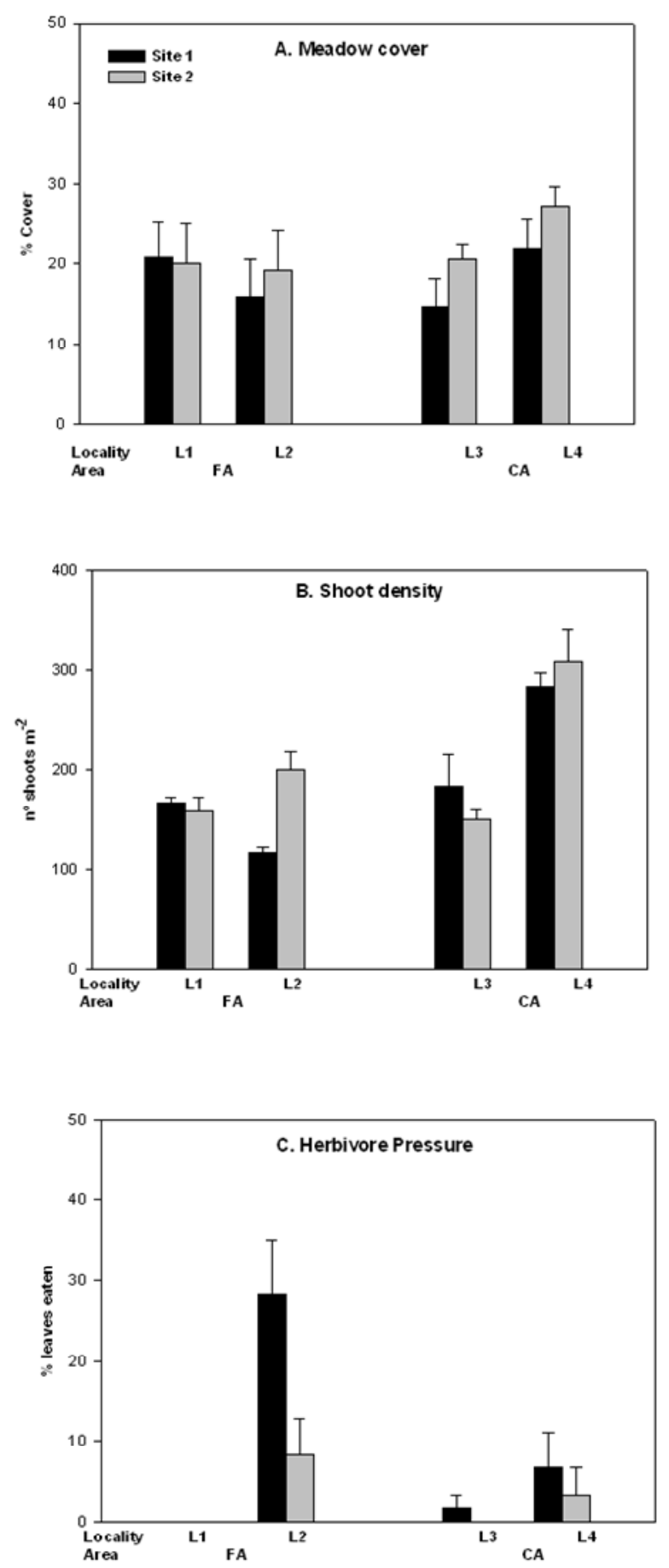
Figures 3:
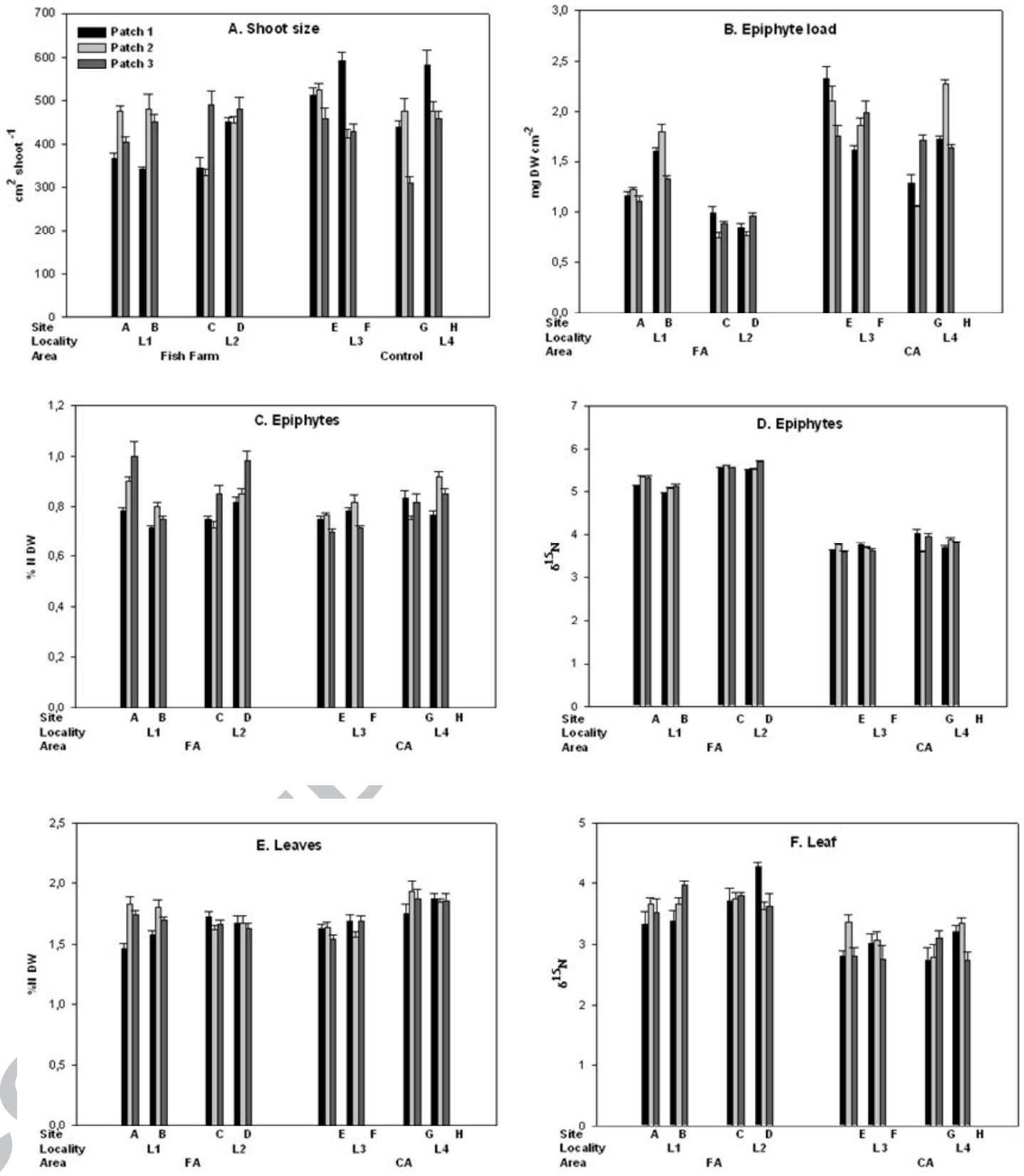